\title{
The Association between Various Earnings and Cash Flow Measures of Firm Performance and Stock Returns: some Iranian evidence
}

\author{
Ali Mazloom \\ Supreme Audit Curt of Birjand, Iran \\ Alireza Azarberahman (Corresponding author) \\ Dept. of Accounting, Islamic Azad University-Mashhad, Iran \\ Tel: +98-915-119-1929Ｅ-mail: a_berahman@yahoo.com
}

Jalal Azarberahman

Supreme Audit Curt of Mashhad, Iran

Received: January 03, 2013 Accepted: February 05, 2013 DOI: 10.5296/ijafr.v3i1.2994

\begin{abstract}
The main purpose of this research is the study of association between various measures of firm performance based on earnings and cash flows and stock returns. This research is an applied research, and its design is semi-empirical, which is done by the method of post-event (past information). The statistical population of the research includes all companies listed in Tehran Stock Exchange (TSE), and its period is nine consecutive years, from 2003 to 2011. Simple and multiple regressions are applied in order to test the hypotheses. Results of the research represent that earning based measures are more related to stock returns than cash flow based measures. Furthermore, earning based measures depict the company performance better than cash flow measures in some companies with higher accruals. But in companies with lower accruals, the company performance cannot be depicted properly neither by earning based nor cash flow based measures.
\end{abstract}

Keywords: Earning based measures, Cash flow based measures, Earning, Cash flows, accruals, and Stock return. 


\section{Introduction}

Applying the historical cash flow data in order to predict the future stock dividend is a complicated process, but predicting the cash flows that are gathered according to cash flow data is more reliable than predicting via mere former earning data considerably. Relying on cash flow data is not correct by itself, especially when some important transactions take place without transferring any cash.

Investors pay a lot of attention to the accounting earning as a predicting device. The current value of corporation (stock prices) is related to the expected earnings stream, and investors usually make their decisions about keeping or selling the stocks according to their expectations of future earning (Jahankhani, et al, 1993). However the usefulness of accrual accounting is undeniable in presenting the financial position and the reporting of performance results, necessity of data existence in cash input and output cannot be ignored, too (Alivar, 1994).

Evaluating the performance of business units has been part of the literature of financial management, financial affairs and accounting in the world since many years age. This point that which measure in "evaluating the companies' performance" is more validated has been the most focused part of theoretical passages in this field.

According to the investors' viewpoint, earnings are a measure of evaluating the management performance. But manipulate and smoothing of earnings by the management has led to some other factors in order to prevent the manipulate and possible misusing, and this is a reason for focusing on the reporting of cash flows as a complimentary statement with main financial statements. Cash money plays an important role in making financial decisions, and ignoring it causes some problems in executing the mentioned decisions or failure in made decisions. Traditional measures like accounting rate of return were replaced by cash flow based measures in evaluating the economical performance and measuring the economic rate of return, because financial researches have presented that in measuring the performance of business units, cash data possess less ambiguity comparing with reported data on the basis of accrual accounting (Nikomaram, et al., 2002).

Accounting earning is the basis of many legal and conventional connections in the society. According to this viewpoint, accounting earning contains financial behavior effects. Therefore accounting earning is important to investors and their decision makings according to the company earning. Actual earnings will be ascertained in the end of the year, so investors may rely on expressed predictions by company's managements (Miar, 1995).

Since the data references of many people, who needs more evaluation and finally make sound decisions, is the annual financial statements of the company, Tehran stock exchange (TSE) has been chosen as the subject of the research for associating between various earnings and cash flow measures of firm performance and stock returns.

According to accounting theory, earnings are considered as a measurement in order to evaluate the performance. Cash flow data can offer a meaningful evaluation of performance in a given period of time. But cash flows might be aberrant, if they consider as a performance 


\section{MlMacrothink}

International Journal of Accounting and Financial Reporting ISSN 2162-3082 2013, Vol. 3, No. 1

index only. However the same events and information are utilized to measure the earning and net cash flows, they cannot be replaced by each other. Thus the association between various income statement measures and cash flow measures of firm performance and stock returns is studied in this research to answer this question: which one of mentioned measurements performs better for evaluating the company performance? And: Do accruals influence the relation among them or not?

\section{Research Literature}

Results of a research by Sasan Miar (1995) revealed that existing information in cash flows statement ratios leads to a substantial increase in correlation among the ratios of income statement and balance sheet with stock returns. But there is a weaker correlation among the cash flows ratios comparing with ratios of income statement and balance sheet in stock returns. Another research which was accomplished via the statistical linear regression method per year and mean of 5 years by Shadi Farshadfar (1999) deduced that there is not any meaningful linear relationship between operating cash flows, operating accruals earning with stock returns. Results of a research by Masood Shahmoradi (2002) showed that there is a meaningful relationship among net profit, operating earning with stock return. According to the results of another research by Rezvan Hejazi and Seddiqeh Doostian, there is a relationship only between net profit and stock returns of listed companies in the stock market, i.e., $1.6 \%$ of stock return changes can be explained by the variable of net profit. Results of a research which was accomplished to test the hypotheses via Pearson correlation and simple linear regression method by Amir Rahim Ashtiani (2005) demonstrated that there is a meaningful relationship among the growing of operating earning, growing of net profit, operating cash flows, investing cash flows with stock return; but there is no meaningful relationship among the growing of trade sale, financing cash flows, and stock return. Results of another research which was accomplished to test the hypotheses by Reza Khoshdel Nezami (2006) present that there is a positive meaningful relationship among the net profit, stock returns, return on equity, and return on assets; there is also a positive meaningful relationship between operating earning with return on equity, return on assets, and growing of net market value in operating assets. But there is no meaningful relationship among free cash flows, stock return, return on equity, and return on assets. And there is only an opposite and meaningful relationship by growing of net market value in operating assets. Therefore operating earning and net profit are influential as accruals earning measurements on the value of share holders and company value. In contrast, free cash flows are irrelevant for evaluating the share holder's equity, and there is no relationship between it and the company values.

The results of Rayburn Judi's (1986) research revealed this point that there is a relationship between operating cash flows and total of accruals with abnormal stock returns. Regarding to correlation between the components of accruals adjustments with abnormal returns and changing of working capital, there was a high correlation, and low correlation with depreciations and changing in taxes delinquent.

Results of the last mentioned research showed that there is a harmony between stock returns and operating cash flows. This harmony exists between the stock returns and total accruals as 


\section{Macrothink}

International Journal of Accounting and Financial Reporting

ISSN 2162-3082 2013, Vol. 3, No. 1

well. He concluded in his research that operating cash flows are a combination of current relevant and adaptable accruals items with a set of information about stock valuation.

Biddel et al., (1997) tried to evaluate the informational content of EVA, residual profit, and two common measures of performance evaluation i.e., operational profit and cash flow, and comparing the relation between EVA and accrual earnings with the company stock return in their research. They deduced that annual earning of accounting has a power two times bigger than EVA in explaining the annual return changes.

\section{Research Methodology}

\subsection{Performance Evaluation Measures}

Performance evaluation measures can be classified into two main general groups: financial and non-financial (Bacidore, et al., 1997). Non-financial class consists of producing, marketing, official, and social measures. Financial ratios are techniques which are suggested as financial measures. Some financial analysts have suggested that combined indices (financial and non-financial) should be utilized together.

Any way, it is not easy to use such indices, because determining the type of indices, finding the correlation between them, and determining their value and weight as well is a difficult task (Watson, Judi, 2005). It is crucial to know the aspect and goal of the performance evaluation. Different people and groups try to evaluate the companies' performance and use its outcome in their decision makings, e.g. shareholders, managements, lenders, creditors, employees, labor unions, government, public and governmental organizations and so on. Considered measurements of a specific party may not be in concordance with other parties. For instance, profitability is one of the most important factors for survival of companies. But in the condition that political or social factors are considered more, profitability may fade a little away. Thus a company, whose performance is acceptable according to managements and share holders' opinion, may not be acceptable in social aspect. Main focus in this research is on investors' view point and their evaluation of the company performance. Table 1 depicts the applied variables and their definitions. 
Table 1. A summary of the research variables and their definitions

\begin{tabular}{|c|c|c|c|}
\hline Variables & Symbol & Variable definition & \\
\hline Stock returns & $\mathrm{R}$ & $R_{i t}=\frac{\left(P_{i t}-P_{i t}-1\right)+D P S-(C-1000)}{P_{i t}-1}$ & Dependent \\
\hline Operating profit ratio & EBIT & $\frac{E B N T_{i t}}{P_{i t}-1}$ & $\begin{array}{l}\text { Independe } \\
\text { nt }\end{array}$ \\
\hline $\begin{array}{l}\text { Operating profit plus depreciation } \\
\text { ratio }\end{array}$ & $\begin{array}{l}\text { EBITD } \\
\text { A }\end{array}$ & $\frac{E T_{i t}+D A_{i t}}{P_{i t}-1}$ & $\begin{array}{l}\text { Independe } \\
\text { nt }\end{array}$ \\
\hline Net profit after tax ratio & NPAT & $\frac{\text { NPAT it }}{P_{i t}-1}$ & $\begin{array}{l}\text { Independe } \\
\text { nt }\end{array}$ \\
\hline $\begin{array}{l}\text { Net cash flows from operating } \\
\text { activities ratio }\end{array}$ & OPCF & $\frac{O P C F_{i t}}{P_{i t}-1}$ & $\begin{array}{l}\text { Independe } \\
\text { nt }\end{array}$ \\
\hline $\begin{array}{l}\text { Net cash flows from investing } \\
\text { activities ratio }\end{array}$ & INVCF & $\frac{\text { NNVCF it }}{P_{\text {it }-1}}$ & $\begin{array}{l}\text { Independe } \\
\text { nt }\end{array}$ \\
\hline $\begin{array}{l}\text { Net cash flows from financing } \\
\text { activities ratio }\end{array}$ & FINCF & $\frac{\text { FuNCF }_{\text {it }}}{P_{\text {it }-1}}$ & $\begin{array}{l}\text { Independe } \\
\text { nt }\end{array}$ \\
\hline Net increase (decrease) on cash ratio & $\mathrm{NCF}$ & $\frac{\text { NCF }_{i t}}{P_{i t-1}}$ & $\begin{array}{l}\text { Independe } \\
\text { nt }\end{array}$ \\
\hline $\begin{array}{l}\text { Net cash flows from operating } \\
\text { activities minus depreciation ratio }\end{array}$ & $\begin{array}{l}\text { OPCFD } \\
\text { A }\end{array}$ & $O P C F D A_{\text {it }}=\frac{(O P C F-D A)_{\text {it }}}{P_{i t-1}}$ & $\begin{array}{l}\text { Independe } \\
\text { nt }\end{array}$ \\
\hline Free cash flows ratio & FCF & $F C F_{\text {it }}=\frac{(O P C F-n)_{\text {it }}}{P_{i t}-1}$ & $\begin{array}{l}\text { Independe } \\
\text { nt }\end{array}$ \\
\hline Accruals & ACC & $A C C=\frac{(E B I T-O P C F)_{i t}}{P_{i t-1}}$ & Control \\
\hline
\end{tabular}

First three independent variables evaluate the earning performance and next six measures are dealing with evaluating the cash flow performance.

\subsection{Model and the research hypotheses}

The research Model is as follows:

$R_{\text {it }}=\infty_{0}+\infty_{1} X_{i t}+\epsilon_{i t} \ldots$ 


\section{Al Macrothink}

International Journal of Accounting and Financial Reporting

ISSN 2162-3082

2013, Vol. 3, No. 1

This model is used for all research hypotheses. Where, $X_{\text {it }}$ is replaced by each of the performance evaluation measures (independent variables) separately.

Following hypotheses are tested in this research:

H1: The correlation between performance measures on the basis of income statement with stock return is more than performance measures on the basis of cash flows with stock return.

H2: Increasing the accrual items causes strengthening the correlation between performance measures on the basis of income statement with stock return, in comparison with performance measures on the basis of cash flows with stock return.

\subsection{Time period of research, Statistical population and Sampling method}

The tested period is considered 9 consecutive years, since 2003 to 2011. Accepted companies in Tehran Stock Exchange are considered as statistical society. Eliminating method is used for sampling, i.e. those companies that possess following features will be chosen and the rest of them will be eliminated:

1- They should have existed in stock exchange since 2003; their presence should be consecutive until 2011.

2- Banks and investing companies were excluded due to their special characteristics.

3- Those companies whose stocks are transacted without any interval during the research period.

Considering mentioned filtering the number of chosen companies in each year is depicted in table 2 .

Table 2. Statistical sample in each year

\begin{tabular}{|l|l|l|l|l|l|l|l|l|l|}
\hline Year & 2003 & 2004 & 2005 & 2006 & 2007 & 2008 & 2009 & 2010 & 2011 \\
\hline No. of companies & 202 & 211 & 216 & 218 & 218 & 218 & 218 & 218 & 218 \\
\hline
\end{tabular}

\subsection{Research method}

Pearson correlation coefficient (confidence level of 0.95) is used to test of dependent and independent variables. Kolmogorov-Smirnov test is used to evaluate the normality; and statistical Durbin-Watson test and Runs test are used to evaluate the independency of the residuals.

Using algorithm is a common technique in order to make homogeneity of returns, and the same method is used in this research as well. Regarding this fact that returns of some companies is negative and negative algorithm cannot be defined, a certain amount is added to total amounts in order to become positive, finally the algorithm will be calculated. Here, the result is a variable that plays the role of a dependent variable in models. Therefore, since the returns mean is used in the hypothesis 1 and the least amount of returns mean during tested 
years have equaled -0.5 , this number $(0.5)$ is added to the returns mean and it is possible to have the algorithm of all. In hypothesis 2, the least amount of returns has approached -1.1 , so this number (1.1) is added to the annual returns of understudy companies.

Nine performance evaluation measurements are checked with stock returns in this research separately, it means $X_{\text {it }}$ is replaced by a different performance evaluation measurement separately every time.

When it is deduced that test of each model is meaningful, modified determination coefficient can be used in order to clear the amount of a group correlation to stock returns.

\section{Research Findings}

\subsection{Test of the first hypothesis}

In this hypothesis, regression model is as follow:

$\ln \left(R_{\mathrm{it}}+0.5\right)=\beta_{0}+\beta_{1} X_{i t}+\epsilon_{\mathrm{it}}$

Table 3. The results of hypothesis 1

\begin{tabular}{|c|c|c|c|c|c|c|}
\hline $\begin{array}{l}\text { Independent } \\
\text { variables }\end{array}$ & $\begin{array}{l}\text { coefficient/ } \\
\text { probability }\end{array}$ & $\left(\beta_{0}\right)$ & $\left(\beta_{1}\right)$ & $\begin{array}{l}\text { correlation } \\
\text { coefficient }\end{array}$ & $\begin{array}{l}\text { modified } \\
\text { coefficient of } \\
\text { determination }\end{array}$ & result \\
\hline \multirow{2}{*}{ EBITDA } & coefficient & -.282 & .635 & .456 & \multirow{2}{*}{.205} & \multirow{2}{*}{ confirmed } \\
\hline & probability & .000 & .000 & .000 & & \\
\hline \multirow{2}{*}{ EBIT } & coefficient & -.308 & .849 & .493 & \multirow{2}{*}{.240} & \multirow{2}{*}{ confirmed } \\
\hline & probability & .000 & .000 & .000 & & \\
\hline \multirow{2}{*}{ NPAT } & coefficient & -.307 & 1.032 & .564 & \multirow{2}{*}{.315} & \multirow{2}{*}{ confirmed } \\
\hline & probability & .000 & .000 & .000 & & \\
\hline \multirow{2}{*}{ OPCFDA } & coefficient & -.218 & .909 & .434 & \multirow{2}{*}{.185} & \multirow{2}{*}{ confirmed } \\
\hline & probability & .000 & .000 & .000 & & \\
\hline \multirow{2}{*}{ OPCF } & coefficient & -.266 & .902 & .441 & \multirow{2}{*}{.191} & \multirow{2}{*}{ confirmed } \\
\hline & probability & .000 & .000 & .000 & & \\
\hline INVCF & coefficient & -.182 & -.573 & -.254 & .060 & confirmed \\
\hline
\end{tabular}




\begin{tabular}{|c|c|c|c|c|c|c|}
\hline & probability & .000 & .000 & .000 & & \\
\hline \multirow{2}{*}{ FINCF } & coefficient & -.048 & -.275 & -.130 & \multirow{2}{*}{.012} & \multirow{2}{*}{ confirmed } \\
\hline & probability & .204 & .048 & .048 & & \\
\hline \multirow{2}{*}{$\mathrm{NCF}$} & coefficient & -.145 & 3.215 & .248 & \multirow{2}{*}{.057} & \multirow{2}{*}{ confirmed } \\
\hline & probability & .000 & .000 & .000 & & \\
\hline \multirow{2}{*}{$\mathrm{FCF}$} & coefficient & -.099 & .243 & .108 & \multirow{2}{*}{.007} & \multirow{2}{*}{ rejected } \\
\hline & probability & .001 & .116 & .116 & & \\
\hline
\end{tabular}

According to the consequences of table $3 \mathrm{P}$-values for all above variables are less that 0.05 , except for FCF which equals 0.116. Therefore existence of a meaningful relation, with 95\% confidence level, among all above independent variables and stock returns is proved - except for FCF. Negative correlation coefficients among independent variables INVCF and FINCE with stock return reveals an opposite relation and positive correlation coefficients among other variables with stock return reveals a direct relation with dependant variables.

According to the consequences of table 3, there is a meaningful relation between dependent and independent variables; and modified coefficient of determinations for EBITDA, EBIT, and NPAT variables equal $0.205,0.240$, and 0.315 respectively; and modified coefficient of determinations for OPCFDA, OPCF, INVCF, FINCF, and NCF variables equal 0.185, 0.191, $0.060,0.012$, and 0.057 respectively. Thus it can be deduced that the correlation among performance measures on the basis of earning with stock return is more than performance measures on the basis of cash flows with stock return because of higher coefficient of determination earning measures (first three variables) and lower coefficient of determination cash flows measures (second six variables).

\subsection{Summary of testing the fundamental hypotheses in hypothesis 1}

Possibility of Smirnov Kolmogrove test for the variables in hypothesis 1 is depicted in table 4. As it can be seen all P-values are bigger than 0.05, so normality of residuals is confirmed with $95 \%$ level of confidence. The amounts of statistics Durbin-Watson test in hypothesis 1 is depicted in table 4 as well; regarding their amounts that are close to 2, independence of residuals can be proved. The amounts of Runs test is depicted in following table, too.

Regarding their value that is bigger than 5\%, independence of residuals is confirmed with 95\% level of confidence as well. Minimum and maximum output amounts of residuals is between -3 and 3 in residuals statistics, therefore the problem of existing the wild values cannot be seen in this model. 
Table 4.Summary of testing the fundamental hypotheses in hypothesis 1

\begin{tabular}{|c|c|c|c|c|c|}
\hline $\begin{array}{l}\text { Independent } \\
\text { variables }\end{array}$ & $\begin{array}{l}\text { Durbin-Watson } \\
\text { statistic }\end{array}$ & $\begin{array}{l}\text { P-value of } \\
\text { periods test }\end{array}$ & $\begin{array}{l}\text { P-values of } \\
\text { normality }\end{array}$ & $\begin{array}{l}\text { Variance } \\
\text { homogeneity }\end{array}$ & $\begin{array}{l}\text { Hypothesis } \\
\text { result }\end{array}$ \\
\hline EBITDA & 1.959 & .051 & .200 & $\begin{array}{l}\text { confirm of } \\
\text { homogeneity }\end{array}$ & accept \\
\hline EBIT & 1.854 & .058 & .200 & $\begin{array}{l}\text { confirm of } \\
\text { homogeneity }\end{array}$ & accept \\
\hline NPAT & 1.690 & .083 & .051 & $\begin{array}{l}\text { confirm of } \\
\text { homogeneity }\end{array}$ & accept \\
\hline OPCFDA & 1.869 & .052 & .200 & $\begin{array}{l}\text { confirm of } \\
\text { homogeneity }\end{array}$ & accept \\
\hline $\mathrm{OPCF}$ & 1.959 & .051 & .200 & $\begin{array}{l}\text { confirm of } \\
\text { homogeneity }\end{array}$ & accept \\
\hline INVCF & 1.951 & .051 & .200 & $\begin{array}{l}\text { confirm of } \\
\text { homogeneity }\end{array}$ & accept \\
\hline FINCF & 1.860 & .054 & .200 & $\begin{array}{l}\text { confirm of } \\
\text { homogeneity }\end{array}$ & accept \\
\hline NCF & 1.954 & .057 & .200 & $\begin{array}{l}\text { confirm of } \\
\text { homogeneity }\end{array}$ & accept \\
\hline $\mathrm{FCF}$ & 1.958 & .059 & .200 & $\begin{array}{l}\text { confirm of } \\
\text { homogeneity }\end{array}$ & accept \\
\hline
\end{tabular}

\subsection{Test of the second hypothesis}

In this hypothesis, regression model is as follow:

$\ln \left(R_{i t}+1.1\right)=\beta_{0}+\beta_{1} X_{i t}+\epsilon_{i t}$

According to the volume of accrual items, companies can be classified in five different classes in order to examine the influence of it on the correlation between performance measures on the basis of income statement and cash flows with stock return. Due to existence of positive and negative accrual items in a business unit life, the use of average method cause to neutralize the effect of positive and negative points on each other. Therefore we consider the data of each year as an independent sample in the company and sort the companies according to the accrual items, and finally categorize them in five equal classes as follow: 
those companies that possess the least volume of accrual items are put in the first class (first quantile) and those companies that possess the most volume of accrual items are put in the fifth class (fifth quantile). Table 5 represents the number of samples in each class.

Table 5.The frequency of samples in each class for testing hypothesis 2

\begin{tabular}{|l|l|l|}
\hline class & frequency & Frequency percentage of each class \\
\hline $1^{\text {st }}$ quantile & 387 & $20 \%$ \\
\hline $2^{\text {nd }}$ quantile & 387 & $20 \%$ \\
\hline $3^{\text {rd }}$ quantile & 389 & $20 \%$ \\
\hline $4^{\text {th }}$ quantile & 387 & $20 \%$ \\
\hline $5^{\text {th }}$ quantile & 387 & $20 \%$ \\
\hline total & 1937 & $100 \%$ \\
\hline
\end{tabular}

According to tables 4 and $5 \mathrm{P}$-values for all mentioned variables is smaller than 0.05 , except for NCF in first class, FINCF in second class, NCF, FINCF, and INVCF in third class, and $\mathrm{NCF}$ and INVCF in fourth and fifth classes. Thus existence of a meaningful relation can be confirmed with $95 \%$ level of confidence between all independent variables, except for mentioned ones, with stock return. As it was predicted in table 4, there is not a big difference between modified coefficient of determination for performance measures on the basis of earnings and performance measures on the basis of cash flows in first class which possesses the least volume of accrual items. Increasing the volume of accrual items leads to this point that modified coefficient of determination for performance measures on the basis of earnings (first three variables) is increased in comparison with performance measures on the basis of cash flows (second six variables); it can be seen vividly in fifth class, that possesses the most volume of accrual items, all the coefficient of determinations of performance measures on the basis of earnings is bigger than $11.1 \%$ and all performance measures on the basis of cash flows are smaller than $2.2 \%$. Consequently, hypothesis 2 can be accepted on the basis of this fact that increasing the accrual items causes strengthening the correlation between performance measures on the basis of income statement with stock return, in comparison with performance measures on the basis of cash flows with stock return.

\subsection{Summary of testing the fundamental hypotheses in hypothesis 2}

P-values of Smirnov Kolmogorov test for the variables in hypothesis 2 represent that all P-values are bigger than 0.05 , so normality of residuals is confirmed with $95 \%$ level of confidence. The statistic of Durbin-Watson test in hypothesis 2 that are close to 2, independence of residuals can be proved. The values of Runs test is depicted in following table, too. Regarding their values that are bigger than $5 \%$, independence of residuals is 
confirmed with $95 \%$ level of confidence as well.

Minimum and maximum output of residuals is between -3 and 3 in residual statistics, therefore the problem of existing the wild values cannot be seen in this model.

Table 6.Evaluating the fundamental hypotheses in hypothesis 2 for $1^{\text {st }}$ quantile

\begin{tabular}{|c|c|c|c|c|c|}
\hline $\begin{array}{l}\text { Independent } \\
\text { variables }\end{array}$ & $\begin{array}{l}\text { Durbin-Watson } \\
\text { statistic }\end{array}$ & $\begin{array}{l}\text { P-value of } \\
\text { periods test }\end{array}$ & $\begin{array}{l}\text { P-values of } \\
\text { normality }\end{array}$ & $\begin{array}{l}\text { Variance } \\
\text { homogeneity }\end{array}$ & $\begin{array}{l}\text { Hypothesis } \\
\text { result }\end{array}$ \\
\hline EBITDA & 1.893 & .055 & .068 & $\begin{array}{l}\text { confirm of } \\
\text { homogeneity }\end{array}$ & accept \\
\hline EBIT & 1.971 & .087 & .200 & $\begin{array}{l}\text { confirm of } \\
\text { homogeneity }\end{array}$ & accept \\
\hline NPAT & 1.874 & .055 & .052 & $\begin{array}{l}\text { confirm of } \\
\text { homogeneity }\end{array}$ & accept \\
\hline OPCFDA & 1.866 & .070 & .065 & $\begin{array}{l}\text { confirm of } \\
\text { homogeneity }\end{array}$ & accept \\
\hline OPCF & 1.967 & .050 & .065 & $\begin{array}{l}\text { confirm of } \\
\text { homogeneity }\end{array}$ & accept \\
\hline INVCF & 1.702 & .053 & .077 & $\begin{array}{l}\text { confirm of } \\
\text { homogeneity }\end{array}$ & accept \\
\hline FINCF & 1.732 & .054 & .077 & $\begin{array}{l}\text { confirm of } \\
\text { homogeneity }\end{array}$ & accept \\
\hline NCF & 1.972 & .060 & .054 & $\begin{array}{l}\text { confirm of } \\
\text { homogeneity }\end{array}$ & accept \\
\hline FCF & 1.867 & .091 & .065 & $\begin{array}{l}\text { confirm of } \\
\text { homogeneity }\end{array}$ & accept \\
\hline
\end{tabular}


Table 7.Evaluating the fundamental hypotheses in hypothesis 2 for $2^{\text {st }}$ quantile

\begin{tabular}{|c|c|c|c|c|c|}
\hline $\begin{array}{l}\text { Independent } \\
\text { variables }\end{array}$ & $\begin{array}{l}\text { Durbin-Watson } \\
\text { statistic }\end{array}$ & $\begin{array}{l}\text { P-value of } \\
\text { periods test }\end{array}$ & $\begin{array}{l}\text { P-values of } \\
\text { normality }\end{array}$ & $\begin{array}{l}\text { Variance } \\
\text { homogeneity }\end{array}$ & $\begin{array}{l}\text { Hypothesis } \\
\text { result }\end{array}$ \\
\hline EBITDA & 1.884 & .065 & .200 & $\begin{array}{l}\text { confirm of } \\
\text { homogeneity }\end{array}$ & accept \\
\hline EBIT & 1.850 & .056 & .200 & $\begin{array}{l}\text { confirm of } \\
\text { homogeneity }\end{array}$ & accept \\
\hline NPAT & 1.938 & .077 & .071 & $\begin{array}{l}\text { confirm of } \\
\text { homogeneity }\end{array}$ & accept \\
\hline OPCFDA & 1.916 & .057 & .200 & $\begin{array}{l}\text { confirm of } \\
\text { homogeneity }\end{array}$ & accept \\
\hline $\mathrm{OPCF}$ & 1.858 & .065 & .200 & $\begin{array}{l}\text { confirm of } \\
\text { homogeneity }\end{array}$ & accept \\
\hline INVCF & 1.766 & .069 & .053 & $\begin{array}{l}\text { confirm of } \\
\text { homogeneity }\end{array}$ & accept \\
\hline FINCF & 1.825 & .054 & .052 & $\begin{array}{l}\text { confirm of } \\
\text { homogeneity }\end{array}$ & accept \\
\hline $\mathrm{NCF}$ & 1.882 & .077 & .200 & $\begin{array}{l}\text { confirm of } \\
\text { homogeneity }\end{array}$ & accept \\
\hline $\mathrm{FCF}$ & 1.832 & .053 & .053 & $\begin{array}{l}\text { confirm of } \\
\text { homogeneity }\end{array}$ & accept \\
\hline
\end{tabular}


Table 8.Evaluating the fundamental hypotheses in hypothesis 2 for $3^{\text {st }}$ quantile

\begin{tabular}{|c|c|c|c|c|c|}
\hline $\begin{array}{l}\text { Independent } \\
\text { variables }\end{array}$ & $\begin{array}{l}\text { Durbin-Watson } \\
\text { statistic }\end{array}$ & $\begin{array}{l}\text { P-value of } \\
\text { periods test }\end{array}$ & $\begin{array}{l}\text { P-values of } \\
\text { normality }\end{array}$ & $\begin{array}{l}\text { Variance } \\
\text { homogeneity }\end{array}$ & $\begin{array}{l}\text { Hypothesis } \\
\text { result }\end{array}$ \\
\hline EBITDA & 1.957 & .053 & .200 & $\begin{array}{l}\text { confirm of } \\
\text { homogeneity }\end{array}$ & accept \\
\hline EBIT & 1.895 & .091 & .066 & $\begin{array}{l}\text { confirm of } \\
\text { homogeneity }\end{array}$ & accept \\
\hline NPAT & 1.861 & .050 & .200 & $\begin{array}{l}\text { confirm of } \\
\text { homogeneity }\end{array}$ & accept \\
\hline OPCFDA & 1.956 & .055 & .200 & $\begin{array}{l}\text { confirm of } \\
\text { homogeneity }\end{array}$ & accept \\
\hline $\mathrm{OPCF}$ & 1.825 & .056 & .084 & $\begin{array}{l}\text { confirm of } \\
\text { homogeneity }\end{array}$ & accept \\
\hline INVCF & 1.979 & .052 & .053 & $\begin{array}{l}\text { confirm of } \\
\text { homogeneity }\end{array}$ & accept \\
\hline FINCF & 1.857 & .051 & .200 & $\begin{array}{l}\text { confirm of } \\
\text { homogeneity }\end{array}$ & accept \\
\hline $\mathrm{NCF}$ & 1.856 & .065 & .054 & $\begin{array}{l}\text { confirm of } \\
\text { homogeneity }\end{array}$ & accept \\
\hline $\mathrm{FCF}$ & 1.804 & .054 & .200 & $\begin{array}{l}\text { confirm of } \\
\text { homogeneity }\end{array}$ & accept \\
\hline
\end{tabular}


Table 9.Evaluating the fundamental hypotheses in hypothesis 2 for $4^{\text {st }}$ quantile

\begin{tabular}{|c|c|c|c|c|c|}
\hline $\begin{array}{l}\text { Independent } \\
\text { variables }\end{array}$ & $\begin{array}{l}\text { Durbin-Watson } \\
\text { statistic }\end{array}$ & $\begin{array}{l}\text { P-value of } \\
\text { periods test }\end{array}$ & $\begin{array}{l}\text { P-values of } \\
\text { normality }\end{array}$ & $\begin{array}{l}\text { Variance } \\
\text { homogeneity }\end{array}$ & $\begin{array}{l}\text { Hypothesis } \\
\text { result }\end{array}$ \\
\hline EBITDA & 1.934 & .050 & .200 & $\begin{array}{l}\text { confirm of } \\
\text { homogeneity }\end{array}$ & accept \\
\hline EBIT & 1.963 & .056 & .200 & $\begin{array}{l}\text { confirm of } \\
\text { homogeneity }\end{array}$ & accept \\
\hline NPAT & 1.943 & .050 & .200 & $\begin{array}{l}\text { confirm of } \\
\text { homogeneity }\end{array}$ & accept \\
\hline OPCFDA & 1.876 & .055 & .200 & $\begin{array}{l}\text { confirm of } \\
\text { homogeneity }\end{array}$ & accept \\
\hline $\mathrm{OPCF}$ & 1.962 & .052 & .095 & $\begin{array}{l}\text { confirm of } \\
\text { homogeneity }\end{array}$ & accept \\
\hline INVCF & 1.857 & .058 & .200 & $\begin{array}{l}\text { confirm of } \\
\text { homogeneity }\end{array}$ & accept \\
\hline FINCF & 1.845 & .065 & .200 & $\begin{array}{l}\text { confirm of } \\
\text { homogeneity }\end{array}$ & accept \\
\hline $\mathrm{NCF}$ & 1.954 & .050 & .200 & $\begin{array}{l}\text { confirm of } \\
\text { homogeneity }\end{array}$ & accept \\
\hline $\mathrm{FCF}$ & 1.857 & .054 & .053 & $\begin{array}{l}\text { confirm of } \\
\text { homogeneity }\end{array}$ & accept \\
\hline
\end{tabular}


Table 10.Evaluating the fundamental hypotheses in hypothesis 2 for $5^{\text {st }}$ quantile

\begin{tabular}{|c|c|c|c|c|c|}
\hline $\begin{array}{l}\text { Independent } \\
\text { variables }\end{array}$ & $\begin{array}{l}\text { Durbin-Watson } \\
\text { statistic }\end{array}$ & $\begin{array}{l}\text { P-value of } \\
\text { periods test }\end{array}$ & $\begin{array}{l}\text { P-values of } \\
\text { normality }\end{array}$ & $\begin{array}{l}\text { Variance } \\
\text { homogeneity }\end{array}$ & $\begin{array}{l}\text { Hypothesis } \\
\text { result }\end{array}$ \\
\hline EBITDA & 1.962 & .061 & .062 & $\begin{array}{l}\text { confirm of } \\
\text { homogeneity }\end{array}$ & accept \\
\hline EBIT & 1.963 & .054 & .193 & $\begin{array}{l}\text { confirm of } \\
\text { homogeneity }\end{array}$ & accept \\
\hline NPAT & 1.963 & .050 & .055 & $\begin{array}{l}\text { confirm of } \\
\text { homogeneity }\end{array}$ & accept \\
\hline OPCFDA & 1.729 & .087 & .054 & $\begin{array}{l}\text { confirm of } \\
\text { homogeneity }\end{array}$ & accept \\
\hline $\mathrm{OPCF}$ & 1.957 & .054 & .051 & $\begin{array}{l}\text { confirm of } \\
\text { homogeneity }\end{array}$ & accept \\
\hline INVCF & 1.961 & .056 & .065 & $\begin{array}{l}\text { confirm of } \\
\text { homogeneity }\end{array}$ & accept \\
\hline FINCF & 1.973 & .075 & .723 & $\begin{array}{l}\text { confirm of } \\
\text { homogeneity }\end{array}$ & accept \\
\hline NCF & 1.861 & .075 & .059 & $\begin{array}{l}\text { confirm of } \\
\text { homogeneity }\end{array}$ & accept \\
\hline $\mathrm{FCF}$ & 1.873 & .056 & .073 & $\begin{array}{l}\text { confirm of } \\
\text { homogeneity }\end{array}$ & accept \\
\hline
\end{tabular}

\section{Conclusion}

As it can be seen in table 11, there is not any meaningful difference in the coefficient of determinations of performance measures in first quantile that possesses the least volume of accrual items of chosen samples. But increasing the volume of accrual items (fifth quantile) leads to this point that the coefficient of determinations of performance measures for earning is meaningfully more than coefficient of determinations of performance measures for cash flows. 


\section{Macrothink \\ International Journal of Accounting and Financial Reporting

Table 11.The summary of research hypotheses testing

\begin{tabular}{|c|c|c|c|c|c|c|}
\hline \multirow{2}{*}{ Research hypotheses } & & \multicolumn{5}{|c|}{ Coefficient of determination } \\
\hline & & \multirow{2}{*}{\begin{tabular}{|l}
$1^{\text {st }}$ \\
quantile \\
.264
\end{tabular}} & \multirow{2}{*}{$\begin{array}{l}2^{\text {nd }} \\
\text { quantile } \\
.258\end{array}$} & \multirow{2}{*}{$\begin{array}{l}3^{\text {rd }} \\
\text { quantile } \\
.225\end{array}$} & \multirow{2}{*}{\begin{tabular}{|l}
$4^{\text {th }}$ \\
quantile \\
.084
\end{tabular}} & \multirow{2}{*}{\begin{tabular}{|l}
$5^{\text {th }}$ \\
quantile \\
.111
\end{tabular}} \\
\hline \multirow{3}{*}{$\begin{array}{l}\text { Performance } \\
\text { measures on the } \\
\text { basis of earnings }\end{array}$} & EBITDA & & & & & \\
\hline & EBIT & .265 & .273 & .259 & .148 & .115 \\
\hline & NPAT & .267 & .244 & .144 & .204 & .120 \\
\hline \multirow{6}{*}{$\begin{array}{l}\text { Performance } \\
\text { measures on the } \\
\text { basis of cash flows }\end{array}$} & OPCFDA & .253 & .244 & .213 & .072 & .019 \\
\hline & $\mathrm{OPCF}$ & .255 & .260 & .246 & .127 & .022 \\
\hline & INVCE & .257 & .031 & $.007^{\odot}$ & $.001^{\odot}$ & $.002^{\odot}$ \\
\hline & FINCF & .124 & $.003^{\odot}$ & $.005^{\oplus}$ & .028 & .010 \\
\hline & $\mathrm{NCF}$ & $.000^{\odot}$ & .056 & $.008^{\odot}$ & $.005^{\odot}$ & $.000^{\odot}$ \\
\hline & FCF & .234 & .078 & .054 & .046 & .014 \\
\hline
\end{tabular}

() significant at $95 \%$ confidence level

As it can see in the above table, increasing the accrual items causes strengthening the correlation between performance measures on the basis of income statement with stock return, in comparison with performance measures on the basis of cash flows with stock return.

As it can be seen in the results of hypothesis 1, the correlation of performance measures on the basis of income statement with stock return is more than performance measures on the basis of cash flows and investors can pay more attention to performance measures on the basis of earnings in order to evaluate the companies' performance.

On the other hand, according to the results of hypothesis 2, however increasing the volume of accrual items reduces the correlation of performing measures with stock return, it leads to this point that correlation in performance measures on the basis of earnings with stock return will be more than correlation in performance measures on the basis of cash flows with stock return. Therefore the volume of accrual items should be considered in choosing a proper measure to evaluate the companies' performance. 


\section{Macrothink}

International Journal of Accounting and Financial Reporting

ISSN 2162-3082

2013, Vol. 3, No. 1

\section{References}

Alivar, Aziz. (1994). Cash flow statement. Center of researches of accounting and auditing, Iran.

Arab Mazar Yazdi, M,. (1995). Incremental information content of cash flows and accruals. University of Tehran. Iran. 61.

Ashtiani, Amir Rahim,. (2005). The study of relationship between accounting ratios and operating cash flows, Investments, financing and stock returns in TSE. Islamic Azad University of Mashhad, Iran.

Bacidore, J.M., Boquist, J.A., Milbourn, T.T and A.V. Thakor. (1997). The search for the best financial performance measure. Financial Analysts Journal. May/June. 11-20.

Banaei, Mikaeil. (1996). The study of causes of preparation of cash flow statement in Iran and preparation of software to help it. University of Tehran. Iran.

Biddle, G.C., Bowen, R.M and J.S. Wallace. (1997). Does EVA Beat Earnings? Evidence on association with stock returns and firm value. Journal of Accounting and Economics, (24), 3, 301-36.

Farshadfar, Shadi,. (1999). The association of accrual earnings and operating cash flows with stock returns. Azad Islamic University of Mashhad, Iran.

Hejazi, Rezvan, and Doostian, Seddiqhe. The study of association between net profit changes and operating cash flow with stock returns in TSE. Accounting Knowledge and Researches. (2), 7 .

Jahankhani, Ali and Abdollah Azad, Farhad. (1993). The study of quality of stocks in Tehran Stock Exchange. Financial Review. (1). 76-77

Khoshdel Nezami, Amin Reza,. (2006). The study of relationship between free cash flows and operating earnings with stock returns and growth of net market value of operating assets in TSE. Islamic Azad University of Mashhad, Iran.

Miar, Sasan. (1995). The study of information content of cash flows financial ratios in companies listed in TSE. Financial Review. 69-84.

Nikomaram, Hashem,. Rahnamaye Rodposhti, Feridon and Hibati, Farshad. (2002). Fundamentals of financial Management. Vol.2. Terme Publisher. PP- 47.

Rayburn, Judi. (1986). The association of operating cash flow and accruals with security returns. Journal of Accounting Research, 24, 112-33.

Robert, Clip. (1996). The information contained in the components of earning. Journal of Accounting Research, 24.

Shahmoradi, Masood,. (2002). The association between accounting earnings and stock returns in firms listed in TSE. University of Shahid Beheshti. 


\section{Macrothink}

International Journal of Accounting and Financial Reporting ISSN 2162-3082 2013, Vol. 3, No. 1

Spigelman, J., (1994). What basis for superior performance? Financial Analysts Journal. 32.

Watson, Judi and Wells, Peter. (2005). The association various earnings and cash flow measures of firm performance and stock returns. School of Accounting, University of Technology, Sydney. 